Relations industrielles

Industrial Relations

\title{
A Social-Minded Bishop
}

\section{Georges-Henri Lévesque}

Volume 4, numéro 1, septembre 1948

URI : https://id.erudit.org/iderudit/1023426ar

DOI : https://doi.org/10.7202/1023426ar

Aller au sommaire du numéro

\section{Éditeur(s)}

Département des relations industrielles de l’Université Laval

\section{ISSN}

0034-379X (imprimé)

1703-8138 (numérique)

Découvrir la revue

Citer cet article

Lévesque, G.-H. (1948). A Social-Minded Bishop. Relations industrielles /

Industrial Relations, 4(1), 1-1. https://doi.org/10.7202/1023426ar

Tous droits réservés (C Département des relations industrielles de l’Université Laval, 1948
Ce document est protégé par la loi sur le droit d'auteur. L'utilisation des services d'Érudit (y compris la reproduction) est assujettie à sa politique d'utilisation que vous pouvez consulter en ligne.

https://apropos.erudit.org/fr/usagers/politique-dutilisation/ 


\section{Bulletin des nelations industrielles}

Volume 4, number 1

QUEBEC

September 1948

\section{Published by the \\ Department of Industrial Relations, Faculty of Social Sciences, Laval University. \\ Georges-Henti Lévesque, o.p., Dean Gérard Tremblay, Director \\ GÉRARD Dion, Assistant-Director Jean Gagné, Secretary \\ CüARLes BÉlanger, Administrator}

The Bulletin is published monthly, September to June inclusively (ten issues a year). Annual subscription: Canada: \$1.50; Foreign: $\$ 2.00$. Single copies: twenty-five cents.

\section{$\because$ All correspondance must be addressed to the Literary Editor GÉrard Dion \\ 2, University Street, Quebec.}

Bulletin dcs relations industrielles \begin{tabular}{ll}
\hline Volume 4, number 1 & September 1948 \\
\hline
\end{tabular}

\section{Contents}

A social-minded Bishop

V.R.Fr. Georges-Henri LÉvesque, o.p. 1

In Memoriam: Egbert Munzer

Léon Dron.. ...

The Canadian and Catholic

Confederation of Labour

Alfred Charpentier.

The Canadian Congress of Labour

Eugene Fonsey.. ... .. ... .. ... ... ........ 5

Lack of job counseling retards

young job hunters.

The right of labor to participate

actively in the life of enterprise

Msgr. P. Pavan.

\section{Contributors}

Charpentier, Alfred, Graduated in Social Sciences (Úniversity of Montreal), Director, Education and Research Bureau, Canadian and Catholic Confederation of Labour Inc.

Dron, Léon, B.A., M.Sc.Soc., Professor, Faculty of Social Sciences.

Forsey, Eugene, B.A., M.A., Ph.D., Director of Research, Canadian Congress of Labour.

LEvesque, V.R.Father Georges-Henri, o.p., Dean, Faculty of Social Sciences.

\section{A SOCIAL-MINDED BISHOP}

Last June 29, on the Feast of the Holy Apostles Peter and Paul, was held the Episcopal Consecration of -His Excellency Monsignor Charles-Omer Garant, Auxiliary Bishop of Quebec.

This was also a great day for the people devoted to social work in Quebec, and especially for the Faculty of Social Sciences of Laval, of which he was one of the founders and has always had in him, from the very beginning, a wise adviser and a firm supporter of all its works as well as with the difficulties it has confronted. Monsignor Garant has also been on the teaching and directing staffs in our Faculty, as far as his hard work at the Faculty of Theology would allow him to do so.

But Monsignor Garant has always remained what his great love for justice and his sacerdotal charity have made out of him: a social apostle. Monsignor Garant has devoted himself entirely to the cause of professional organization, in Quebec. Imbued with the spirit of the social Encyclicals and attracted by all the good that could and had to be done in our society, he has given himself totally to the difficult - and often thankless - task of inspiring and setting up for it the appropriate institutions capable of maintaining in it order and peace. To him Quebec owes the glory of having been the great instigator of the movement of professional organization of employers, in Quebec.

What is amazing in the career of this great leader is this: while making the employers feel their urgent need of organization, never has he ceased teaching them, at the same time, to have full regard to the workers' just demands. This attitude is easily explainable in Monsignor Garant, for he is a man who sees social life, not as a nevessary struggle between irreconcilable enemies, but as a hard and salutary effort of fraternity between men redeemed by love.

Could it be otherwise in him who, one day, on receiving the plenitude of priesthood, would take as his motto: \&n iustitia et carifate 》 - two words, or rather two things with which the whole of his life has been assimilated.

To our new and sympathetic Auxiliary Bishop, we are deeply pleased to address our warmest congratulations and to express our earnest wishes. There is no further need to add that he shall always find, in « his » Faculty of Social Sciences, the full co-operation he is entitled to expect, and which our Faculty shall be always proud and glad to give him.

Georges-Henri Lévesque, o.p. 